\title{
Characterization of Immobilized Biomass by Amplified rDNA Restriction Analysis (ARDRA) in an Anaerobic Sequencing-Batch Biofilm Reactor (ASBBR) for the Treatment of Industrial Wastewater
}

\author{
Arnaldo Sarti *, Eloisa Pozzi and Marcelo Zaiat \\ Laboratório de Processos Biológicos; Departamento de Hidráulica e Saneamento; Escola de Engenharia de São \\ Carlos; Universidade de São Paulo; Av. João Dagnone, 1100; Santa Angelina; 13563-120; São Carlos - SP - Brasil
}

\begin{abstract}
The performance of an anaerobic sequencing-batch biofilm reactor (ASBBR-laboratory scale- $14 L$ ) containing biomass immobilized on coal was evaluated for the removal of elevated concentrations of sulfate (between 200 and $\left.3,000 \mathrm{mg} \mathrm{SO}_{4}^{-2} \cdot \mathrm{L}^{-1}\right)$ from industrial wastewater effluents. The ASBBR was shown to be efficient for removal of organic material (between $90 \%$ and 45\%) and sulfate (between 95\% and $85 \%$ ). The microbiota adhering to the support medium was analyzed by amplified ribosomal DNA restriction analysis (ARDRA). The ARDRA profiles for the Bacteria and Archaea domains proved to be sensitive for the determination of microbial diversity and were consistent with the physical-chemical monitoring analysis of the reactor. At 3,000 $\mathrm{mg} \mathrm{SO}_{4}^{-2} \cdot \mathrm{L}^{-1}$, there was a reduction in the microbial diversity of both domains and also in the removal efficiencies of organic material and sulfate.
\end{abstract}

Key words: sulfate removal, support medium, endonucleases, ARDRA, batch reactor, ASBBR

\section{INTRODUCTION}

Industrial wastewater with elevated concentrations of sulfur compounds (sulfate and sulfide) requires suitable treatment to meet legal requirements for disposal. In the state of São Paulo, State Decree 8468 of 1976 established maximum concentrations of $1,000 \mathrm{mg} \mathrm{SO}_{4}{ }^{2-} / \mathrm{L}$ of sulfate (article $19 \mathrm{a}$ ) and 1.0 $\mathrm{mg} / \mathrm{L}$ (CONAMA 357) of sulfides in liquid effluents directly or indirectly disposed of into receiving water bodies.

The biological removal of sulfate is an alternative with a greater cost-benefit ratio in relation to physical-chemical methods (Maree et al. 1991). Anaerobic sequencing-batch biofilm reactors (ASBBR) with immobilized biomass have been shown to be adequate for the removal of sulfate from wastewater (Sarti et al. 2006 and Sarti et al. 2010) and the removal of large quantities of organic material (Ribas et al. 2008).

Sulfate reduction in completely sulfidogenic reactors results in sulfides with the oxidation of organic material by sulfate-reducing bacteria (SRB).

The SRB can grow in a wide range of wastewaters: industrial effluents, acidified waters resulting from drainage in metal extraction processes, simultaneous removal of metals, and in the desulfurization of gas emissions (Lens et al. 1998). These microorganisms are divided in two main groups: SRB that incompletely degrade organic material to acetate (reaction 1; butanol is the example substrate) and SRB that completely

*Author for correspondence: arnaldosarti@gmail.com 
degrade organic material to carbon dioxide (reaction 2; here, acetate is the substrate).

Due to its toxicity, the sulfide produced constitutes the main problem associated with the anaerobic treatment of wastewater rich in sulfate. The inhibitory effect of sulfide is probably caused by $\mathrm{H}_{2} \mathrm{~S}$ (non-ionized). Low $\mathrm{pH}$ values and low temperatures increase its toxicity, as well as favor the formation of ionized sulfide. Besides the $\mathrm{pH}$, the $\mathrm{COD} /$ sulfate ratio also influences the susceptibility of microorganisms to the toxicity of sulfide.

$$
\begin{aligned}
& \mathrm{C}_{4} \mathrm{H}_{9} \mathrm{OH}+\mathrm{SO}_{4}^{-2} \rightarrow 2 \mathrm{CH}_{3} \mathrm{COO}^{-}+\mathrm{HS}^{-}+\mathrm{H}^{+}+\mathrm{H}_{2} \mathrm{O} \\
& \mathrm{CH}_{3} \mathrm{COO}^{-}+\mathrm{SO}_{4}^{-2} \rightarrow 4 \mathrm{HCO}_{3}^{-}+2 \mathrm{HS}^{-}
\end{aligned}
$$

In mixed cultures, as in those existing in wastetreatment bioreactors in the presence of sulfate, the sulfate-reducing bacteria (SRB) compete with the methanogenic Archaea for the same substrates, acetate and hydrogen. Therefore, the objective of this study was to characterize the diversity of the microbiota adhering to the coal particles in the ASBBR for the domains Bacteria and Archaea by using the amplified ribosomal DNA restriction analysis technique (ARDRA) and to establish a possible relation with the reactor performance in terms of the removal of sulfate and organic material.

The possibility of characterizing microbial diversity through molecular biology techniques without the need to isolate microorganisms has revolutionized microbial ecology. In the ARDRA technique, fragments from the $16 \mathrm{~S}$ region of the ribosomal RNA (rRNA) sequences, amplified as complementary DNA (cDNA) by the polymerase chain reaction (PCR) from a DNA sample of the community, are digested with restriction endonucleases. These enzymes cleave the DNA at specific sites, producing double-stranded fragments of precisely defined sizes. These fragments are separated by agarose- or polyacrylamide-gel electrophoresis (Massol-Deya et al. 1995).

The objective of this study was to establish a relationship between the microbial diversity present in the ASBBR reactor and the operational results obtained for the removal of sulfate and organic material at various sulfate concentrations.

\section{MATERIAL AND METHODS}

Wastewater was collected from a chemical plant located in the region of São Carlos, SP with a high sulfate concentration $(\sim 200 \mathrm{~g} / \mathrm{L})$, in this case resulting from the sulfonation of vegetable oils. To permit the biological treatment of this sulfate-rich effluent, a strategy for a gradual increase in sulfate concentration $(250,500,1,000,2,000$ and 3,000 $\mathrm{mg} / \mathrm{L}$ ) was chosen to be applied to the ASBBR.

The sulfate-rich industrial effluent was mixed with other wastewater generated in the production of melamine resin. The organic material $(155 \mathrm{~g}$ $\mathrm{COD} / \mathrm{L}$ ) present in this residue was $99 \%$ butanol, forming the carbon source (electron donor) for the reduction of sulfate in the ASBBR.

The ASBBR (Anaerobic Sequencing-Batch Biofilm Reactor) was constructed at the laboratory scale (total volume: 14 L) of acrylic and maintained at a controlled temperature of $25 \pm 1^{\circ} \mathrm{C}$. The support medium used for adhesion of the biomass was $6 \mathrm{~kg}$ of coal (diameter $=10$ to 20 $\mathrm{mm})$, resulting in a bed porosity $(\varepsilon)$ of $50 \%$ and a liquid treatment volume of $7 \mathrm{~L}$. The total operational cycle was 48 hours, divided into the following steps: feeding $(1 \mathrm{~h})$, reaction with continuous recirculation $(46 \mathrm{~h})$ and drainage $(1 \mathrm{~h})$. Agitation was maintained by ascending liquid recirculation using a peristaltic pump. Figure 1 and Table 1 present the main characteristics of the ASBBR. The reactor was inoculated with anaerobic granular biological sludge from the treatment of effluent from a poultry slaughterhouse. The concentration of sulfate in the reactor influent was gradually increased from 250 $\mathrm{mg} \mathrm{SO}_{4}^{-2} / \mathrm{L}$ (Stage 1) to $500 \mathrm{mg} \mathrm{SO}_{4}^{-2} / \mathrm{L}$ (Stage 2), then $1,000 \mathrm{mg} \mathrm{SO}_{4}{ }^{-2} / \mathrm{L}$ (Stage 3), 2,000 $\mathrm{mg} \mathrm{SO}_{4}{ }^{-2} / \mathrm{L}$ (Stage 4), and finally $3,000 \mathrm{mg} \mathrm{SO}_{4}^{-2} / \mathrm{L}$ (Stage 5). To reach these concentrations, dilution of the industrial effluent was necessary as well as the addition of the carbon source (wastewater from melamine resin) to maintain the $\mathrm{COD} /$ sulfate ratio between 1.8 and 4.0 .

Monitoring of the ASBBR was performed by monitoring $\mathrm{pH}, \mathrm{COD}$ (chemical oxygen demand), Sulfate $\left(\mathrm{SO}_{4}{ }^{2-}\right)$, and Total Dissolved Sulfide (TDS) concentrations according to the methodology described by APHA (2005). The total volatile acids were also determined, including acetic acid (Dillalo and Albertson, 1961).

At the end of each operational cycle, that is, for each sulfate concentration studied, floating biomass along with five particles of coal from the middle region of the reactor were removed, and the biomass was separated from the coal with the 
aid of a soft polyethylene bristle brush. After homogenization of this material, genomic DNA was extracted (Griffiths et al., 2000), and amplification of ribosomal 16S sequences was performed using the polymerization chain reaction (PCR). For the domain Bacteria, two universal primers were used: $27 \mathrm{~F}$ (5' AGA GTT TGA TCC TGG CTC AG 3') and 1522R (5' AAG GAG GTG ATC CAG CCG CA 3'). The following primers were used for the domain Archaea: $1 \mathrm{AF}$
(5 TCY GKT TGA TCC YGS CRG AG 3`) and 1100 AR (5` TGG GTC TCG CTC GTT G 3`). The PCR reactions for the rRNA 16S followed the methodologies described by Fernández et al. (1999) for Bacteria and that reported by Hales et al. (1996) for Archaea. The PCR products were submitted to amplified rDNA restriction analysis (ARDRA) (Massol-Deyá et al. 1995), i.e., digested with the endonucleases Alu I and Hae III, followed by agarose-gel electrophoresis.

Table 1 - Construction characteristics of the ASBBR (laboratory scale).

\begin{tabular}{lc}
\hline Characteristics & ASBBR \\
\hline Material & Acrylic \\
Height $(\mathrm{L})$ & $820 \mathrm{~mm}$ \\
Diameter $(\mathrm{D})$ & $150 \mathrm{~mm}$ \\
Coal mass $(\varepsilon=0.5)$ & $6 \mathrm{Kg}$ \\
Liquid bed volume $\left(\mathrm{V}_{\mathrm{L}}\right)$ & $6 \mathrm{~L}$ \\
Total bed volume $\left(\mathrm{V}_{\mathrm{TL}}\right)$ & $12 \mathrm{~L}$ \\
Head-space volume $\left(\mathrm{V}_{\mathrm{H}}\right)$ & $1 \mathrm{~L}$ \\
Additional volume $\left(\mathrm{V}_{\mathrm{A}}\right)$ & $1 \mathrm{~L}$ \\
$*$ Liquid volume $\left(\mathrm{V}_{\mathrm{A}}+\mathrm{V}_{\mathrm{L}}\right)$ & $7 \mathrm{~L}$ \\
Total reactor volume $\left(\mathrm{V}_{\mathrm{TL}}+\mathrm{V}_{\mathrm{H}}+\mathrm{V}_{\mathrm{A}}\right)$ & $14 \mathrm{~L}$ \\
Useful volume $\left(\mathrm{V}_{\mathrm{TL}}+\mathrm{V}_{\mathrm{A}}\right)$ & $13 \mathrm{~L}$ \\
\hline$*$ Liquid to be treated volume & \\
$\mathrm{V}_{\mathrm{A}}$-Liquid level for pump suction & \\
\hline
\end{tabular}

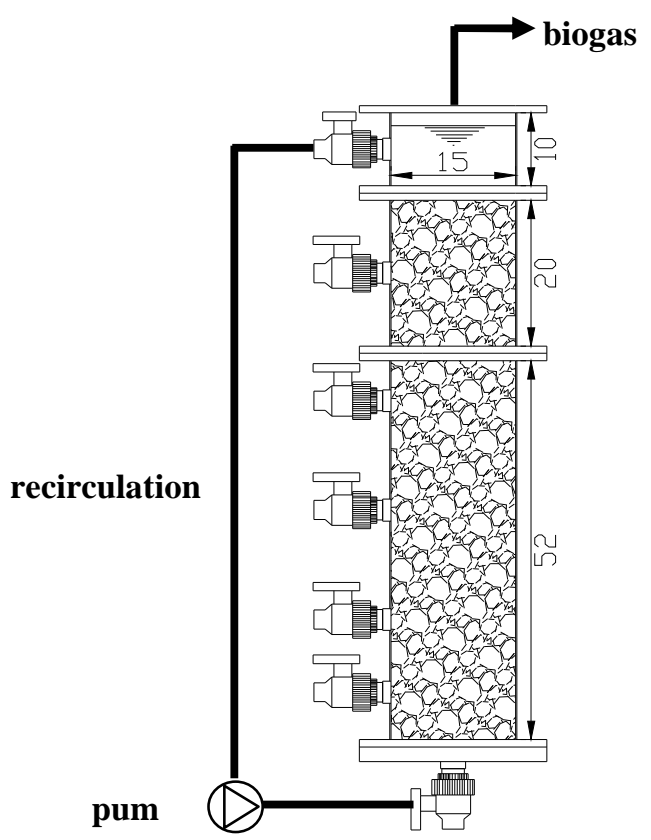

Figure 1 - Flow diagram of the ASBBR (measurements in $\mathrm{cm}$ ). 


\section{RESULTS AND DISCUSSION}

Tables 2 and 3 present the results of monitoring both the influents (Table 2) and effluents (Table 3) of the ASBBR reactor at the five different concentrations of sulfate applied.

The results for sulfate-removal efficiency were related to the $\mathrm{COD} /$ sulfate ratios for a total of 65 operational cycles and are shown in Figure 2. Figure 3 shows the results for COD removal during the 65 cycles.

During the operation of the reactor, significant results were obtained in terms of sulfate removal.
In this system, the following loads were reached: application of $2.2 \mathrm{~g} \mathrm{SO}_{4}{ }^{2-} /$ cycle with an average efficiency of $85 \%$ and a removal of $18.8 \mathrm{~g} \mathrm{SO}_{4}{ }^{2-}$ /cycle (Tables 1 and 2 and Fig. 1). In terms of COD, during the 65 cycles a gradual reduction in the organic-material-removal efficiency was observed, accentuated in Stage $3\left(1,000 \mathrm{mg} \mathrm{SO}_{4}{ }^{-}\right.$ ${ }^{2} / \mathrm{L}$; Tables 1 and 2 and Figure 2, possibly due to the inhibition of methanogenesis. It should also be noted that the applied load in terms of COD was generated by the addition of wastewater from melamine resin as an electron donor for the sulfate-reduction process.

Table 2 - Average values of the influent variables applied to the ASBBR reactor in the different operational stages.

\begin{tabular}{lccccc}
\hline \multicolumn{1}{c}{ Variables } & Stage 1 & Stage 2 & Stage 3 & Stage 4 & Stage 5 \\
\hline Number of cycles & 16 & 10 & 22 & 11 & 6 \\
$\mathrm{SO}_{4}{ }^{-2}(\mathrm{mg} / \mathrm{L})$ & $289 \pm 26$ & $572 \pm 70$ & $1048 \pm 72$ & $2172 \pm 122$ & $3179 \pm 176$ \\
$\mathrm{COD}_{\text {Total }} /\left[\mathrm{SO}_{4}{ }^{-2}\right]$ & $2.60 \pm 0.54$ & $3.09 \pm 0.22$ & $3.67 \pm 0.45$ & $3.32 \pm 0.42$ & $3.67 \pm 0.19$ \\
$\mathrm{COD}$ & $762 \pm 205$ & $1,757 \pm 132$ & $3,839 \pm 442$ & $7,190 \pm 827$ & $11,652 \pm 763$ \\
$\mathrm{TVA}(\mathrm{mg} / \mathrm{L})$ & $20.7 \pm 10.8$ & $17.7 \pm 3.9$ & $29.8 \pm 9.8$ & $26.5 \pm 4.1$ & $22.7 \pm 3.6$ \\
$\mathrm{pH}$ & $6.2-7.4$ & $6.5-7.4$ & $6.6-7.5$ & $5.9-7.0$ & $5.9-6.5$ \\
\hline
\end{tabular}

Table 3 - Average values of the effluent variables obtained for the performance of the ASBBR reactor in the different operational stages.

\begin{tabular}{lccccc}
\hline Variables & Stage 1 & Stage 2 & Stage 3 & Stage 4 & Stage 5 \\
\hline Number of cycles & 16 & 10 & 22 & 11 & 6 \\
$\mathrm{SO}_{4}^{-2}(\mathrm{mg} / \mathrm{L})$ & $103.6 \pm 29.5$ & $31.9 \pm 15.2$ & $56.4 \pm 29.5$ & $247.8 \pm 128.4$ & $485.8 \pm 47.4$ \\
$* \mathrm{TDS}(\mathrm{mg} / \mathrm{L})$ & $1.26 \pm 0.30$ & $214.6 \pm 50.3$ & $122.8 \pm 68.8$ & $73.9 \pm 26.9$ & $197.7 \pm 6.1$ \\
$\mathrm{COD}_{\text {Total }}(\mathrm{mg} / \mathrm{L})$ & $55 \pm 18$ & $214 \pm 50$ & $1,994 \pm 494$ & $3,773 \pm 768$ & $7,933 \pm 408$ \\
$\mathrm{COD}_{\text {Filtered }}(\mathrm{mg} / \mathrm{L})$ & $28 \pm 12$ & $157 \pm 55$ & $1,904 \pm 474$ & $3,637 \pm 784$ & $7,740 \pm 426$ \\
$* * \mathrm{TVA}(\mathrm{mg} \mathrm{HAc} / \mathrm{L})$ & $24 \pm 7.2$ & $32 \pm 14$ & $675 \pm 99$ & $1,322 \pm 174$ & $2,010 \pm 59$ \\
$\mathrm{pH}$ & $6.3-7.4$ & $6.5-7.7$ & $6.4-7.7$ & $7.2-7.7$ & $6.4-6.8$ \\
\hline
\end{tabular}

*Total Dissolved Sulfide

** Total volatile acids (as acetic acid; HAc)

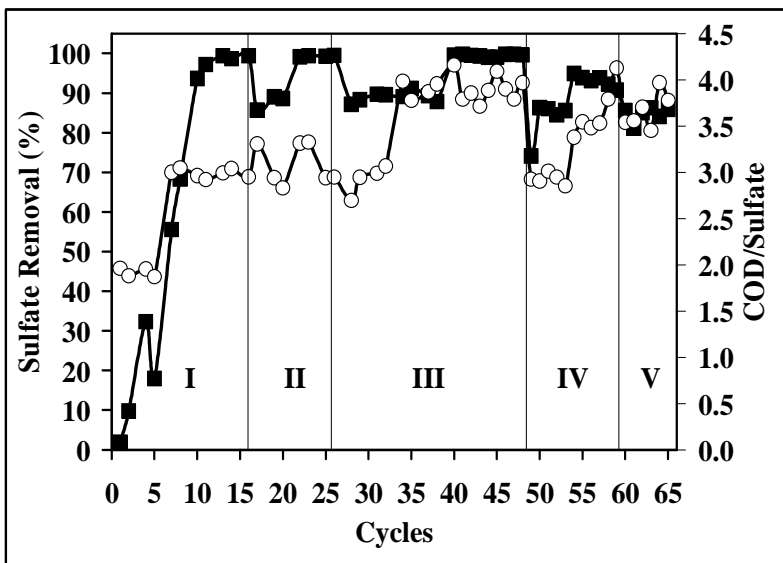

Figure 2 - Temporal variation of the sulfate removal efficiency (ם) and the $\mathrm{COD} /\left[\mathrm{SO}_{4}{ }^{2-}\right]$ ratio (o) applied to the ASBBR in the various operational stages. 


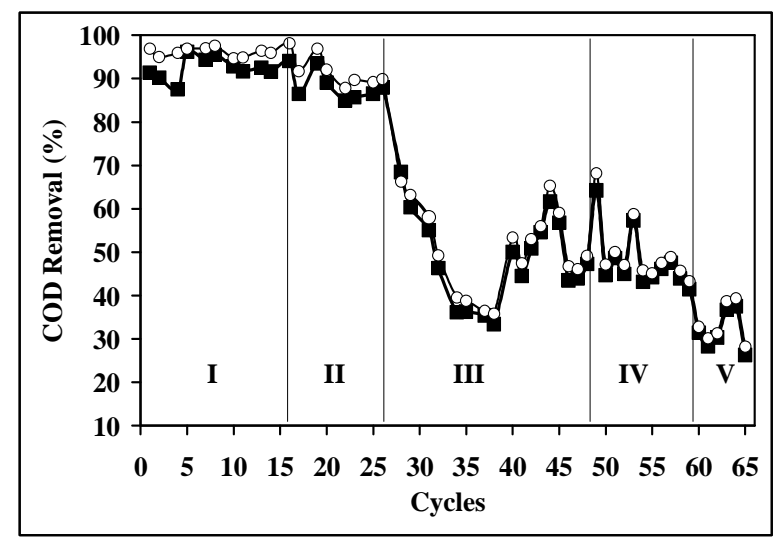

Figure 3 - Temporal variation of the removal efficiency in terms of $\operatorname{COD}_{\text {Total }}(\boldsymbol{\square})$ and $\operatorname{COD}_{\text {Filtered }}$ (o) of the ASBBR in the various operational stages.

The applied organic loads varied from 5.33 to $81.56 \mathrm{~g} \mathrm{COD} /$ cycle in the various stages, and the mean removal efficiencies were greater than $90 \%$ in Stages 1 and 2, decreasing to an average of $45 \%$ in later stages. The low efficiency of organicmaterial removal observed in Stage 5 was linked to the high concentration of residual COD, principally composed of total volatile acids (TVA), which reached a concentration of 2,000 mg HAc/L (Table 3), associated with the elevated concentration of dissolved sulfides $(190 \mathrm{mg} / \mathrm{L}$; Table 3) generated during sulfate reduction. Those volatile acids not consumed by the methanogenic pathway were carried out of the reactor together with the sulfides in the ASBBR effluent (Nagpal et al., 2000).

In both endonuclease digestion tests with the domain Bacteria (Fig. 4, a and b), differences were observed in the banding patterns of the 16S rRNA fragments amplified from the inoculum and the microbiota established on the support medium for all studied conditions.

In Stages 1 and 2, the banding patterns were similar. Beginning in Stage 3, alterations were observed in these patterns, which resembled the bands in Stage 4. Stage 3 showed an average sulfate reduction of $95 \%$ ( $\max : 99.8 \%$ ), and in Stage 4, 88\% (max: 95\%) was obtained. However, in Stage 5, the average sulfate reduction was $85 \%$ (max: 86\%), and there was a significant change in the ARDRA profile, apparently indicating a diminishing bacterial diversity in the reactor at this sulfate concentration.
In digestions with the endonucleases Alu $I$ and Hae III for the domain Archaea (Fig. 4, c and d), differences were also observed in both between the ARDRA profiles of the inoculum and the microbiota established on the support medium at all conditions studied. Apparently, the selected methanogenic Archaea maintained themselves in all test situations, except in Stage 5. In this stage, the average total dissolved sulfide concentration was $197.7 \pm 6.1 \mathrm{mg} \cdot \mathrm{L}^{-1}$ (max: $206 \mathrm{mg} \cdot \mathrm{L}^{-1}$ ). As the $\mathrm{pH}$ in the effluent decreased from 7.7 (Stage 3) to 6.4 (Stage 5), this indicated more un-ionized sulfide, i.e., a greater $\mathrm{H}_{2} \mathrm{~S}$ concentration in the liquid medium. The reduction in $\mathrm{pH}$ was caused by the increase in total volatile acid (TVA) concentration due to the partial oxidation of butanol by the sulfate-reducing bacteria (SRB) to produce acetic acid (Table 3 ).

The presence of sulfide in the form of $\mathrm{H}_{2} \mathrm{~S}$ at high concentrations likely inhibited methanogenic activity. The population of methanogens appears to have disappeared from the reactor at this stage, as confirmed by the absence of 16S rRNA fragments in the electrophoresis (Fig. 4c, S5 and $4 \mathrm{~d}$, S5). The disappearance of methanogenic Archaea confirms the increase in TVA concentration that generated the residual COD. Possibly, the butanol present in the melamine wastewater was partially oxidized by the SRB and converted to acetate, which was not totally consumed by the methanogenic organisms since they were no longer present in the system. 


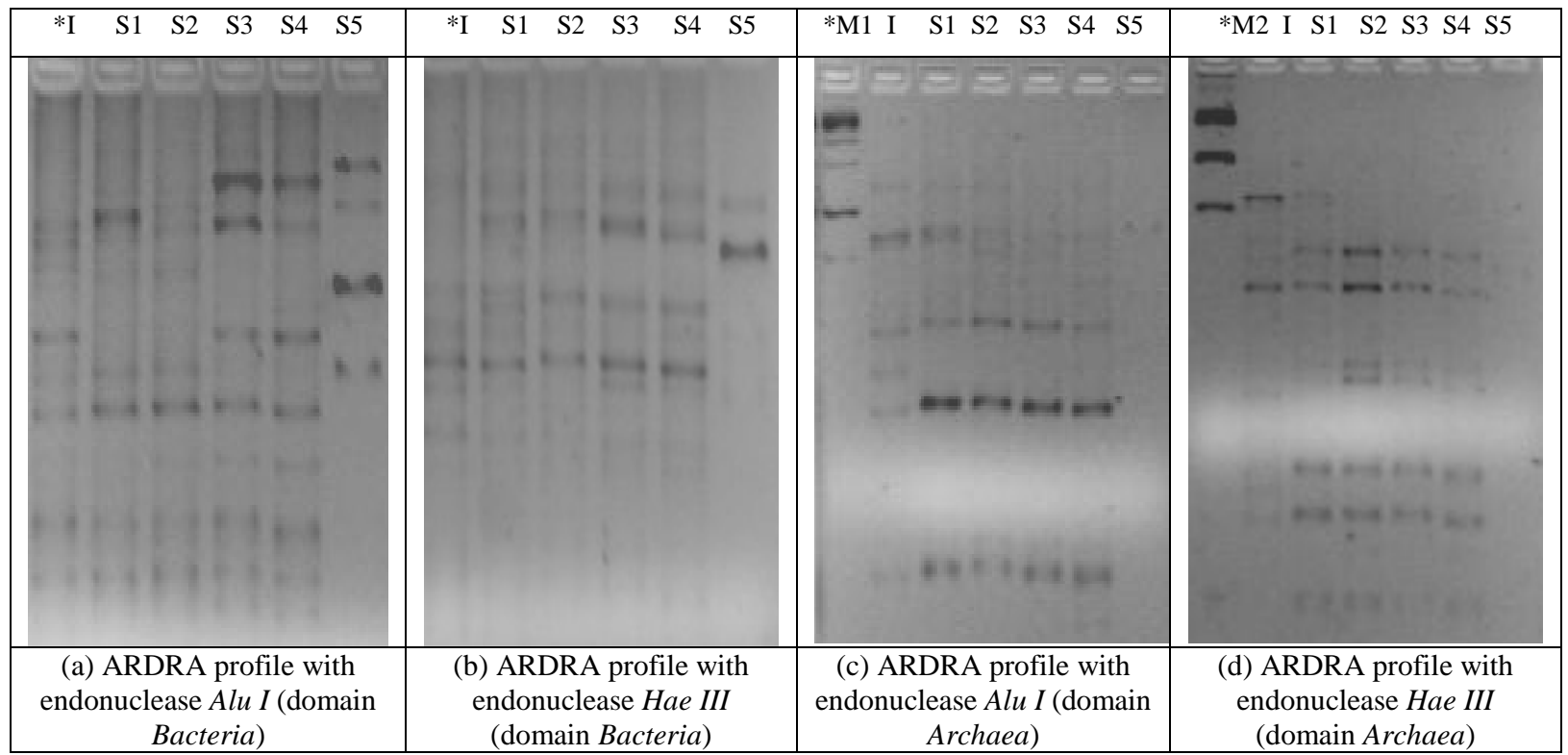

Figure 4 - ARDRA profiles for the domains Bacteria (a and b) and Archaea (c and d). Legend:*I (inoculum); S1 (250 mg SO$\left.{ }_{4}^{-2} / \mathrm{L}\right) ; \mathrm{S} 2$ (500 mg SO$\left.{ }_{4}^{-2} / \mathrm{L}\right) ; \mathrm{S} 3\left(1,000 \mathrm{mg} \mathrm{SO}_{4}^{-2} / \mathrm{L}\right) ; \mathrm{S} 4$ $\left(2,000 \mathrm{mg} \mathrm{SO}_{4}^{-2} / \mathrm{L}\right) ; \mathrm{S} 5\left(3,000 \mathrm{mg} \mathrm{SO}_{4}^{-2} / \mathrm{L}\right) ; \mathrm{M} 1$ (DNA label at 10,000 bp); M2 (DNA label at 2,000 bp).

\section{CONCLUSIONS}

The ASBBR reactor with biomass immobilized on coal was shown to be sufficient for the removal of organic material and elevated concentrations of sulfate in industrial wastewater effluent, at concentrations varying from 250 to $3,000 \mathrm{mg} \mathrm{SO}_{4}{ }^{-}$ ${ }^{2} / \mathrm{L}$. The ARDRA profiles for the domains Bacteria and Archaea proved to be a sensitive tool for the determination of microbial diversity, especially in Stage $5\left(3,000 \mathrm{mg} \mathrm{S_{4 }}{ }^{-2} / \mathrm{L}\right)$. It is possible that this concentration was the upper limit for this reactor since there was a reduction in microbial diversity for both domains as well as in the removal efficiencies of organic material and sulfate.

\section{ACKNOWLEDGEMENTS}

The authors acknowledge the financial support received for this work from FAPESP- Fundação de Amparo a Pesquisa do Estado de São Paulo given to the Thematic Project n. 2005-51702-9 and 07/08335-09 (research grants).

\section{REFERENCES}

Fernandez A, Huang S, Seston S, Xing J.; Hickey, R.; Criddle, C.; Tiedje, JM, et al. How Stable is Stable? Function versus Community Composition. Appl. and Environ. Microbiol. 1998; 65: 356-365.

Dilallo R, Albertson OE. Volatile Acids by Direct Tritation. Journal WPCF. 1961; 33: 356-365.

Griffiths RI, Whiteley AS, O'Donnell AG. Rapid Method for Coextration of DNA from Natural Environments for Analysis of Ribosomal DNA and rRNA-based Microbial Community Composition. Appl. and Environ. Microbiol. 2000; 366: 5488-5491.

Hales BA, Edwards C, Ritchie DA, Hall G, Pickup RW, Saunders JR, et al. Isolation and Identification of Methanogen-Specific DNA from Blanket Bog Peat by PCR Amplification and Sequence Analysis. Appl. and Environ. Microbiol. 1996; 62: 668-675.

Lens PNL, Visser A, Janssen AJH, Hulshoff Pol LW; Lettinga G. Biotechnological treatment of sulfate-rich wastewater. Critical Rev. in Environ. Sci. and Technol.1998; 28: 41-88.

Maree JP, Hulse G, Dods D, Schutte, CE. Pilot Plant Studies on Biological Sulphate Removal from Industrial Effluent. Water Science and Technol. 1991; 23: 1293-1300. 
Massol-Deyá A, Odelson DA, Hickey RF, Tiedje JM. (1995), Bacterial Community Fingerprinting of Amplified 16S and 16-23S Ribosomal DNA Gene Sequences and Restriction Endonuclease Analysis (ARDRA), p. 3.3.2:1-8 In A. D. L. Akkermans, J. D. van Elsas, and F. J. de Bruijn (ed.), Molecular microbial ecology manual. Kluwer Academic Publishers, Dordrecht, The Netherlands.

Nagpal S, Chuichulcherm S, Peeva L, Livingston A. (2000), Microbial Sulfate Reduction in a Liquid-Solid Fluidized Bed Reactor. Biotechnol Bioengineering. 2000; 70: 370-379.

Sarti A, Pozzi E, Chinalia FA, Zaiat M, Foresti E. The Performance of an Anaerobic Sequencing Batch Biofilm Reactor Treating Domestic Sewage Colonized by Anoxygenic Phototrophic Bacteria. Chemosphere, 2006; 62: 1437-1443.

Sarti A, Pozzi E, Chinalia FA, Ono AF, Foresti E. Microbial Processes and Bacterial Population Associated to Anaerobic Treatment Populations Associated to Anaerobic Treatment of Sulfate-Rich Wastewater. Process Biochem. 2010; 45: 164-170.
Standard Methods for the Examination of Water and Wastewater (2005), American Public Health Association / American Water Works Association / Water Environment Federation, $21^{\text {th }}$ ed. Washington, DC, USA.

Ribas MMF, Chinalia F, Pozzi E, Foresti, E. Microbial Succession within an Anaerobic Sequencing Batch Biofilm Reactor (ASBBR) Treating Cane Vinasse at 55 ${ }^{\circ}$. Braz Arch Biol and Technol. 2008; 52: 10271036.

Received: January 24, 2011; Revised: February 16, 2011; Accepted: April 23, 2012. 
PAGINA

EM

BRANCO 